\title{
相対水深が小さい場における河床表層状態 および鉛直構造と粗度の評価 ESTIMATION OF FLOW RESISTANCE CONSIDERING BOTH BED SURFACE CONDITION AND VERTICAL STRUCTURE
}

\author{
溝口 敦子 \\ Atsuko MIZOGUCHI \\ 正会員 博(工) 名城大学准教授 理工学部社会基盤デザイン工学科 \\ （干468-8502 名古屋市天白区塩釜口1-501）
}

\begin{abstract}
These days, 2-dimentional numerical simulation of changing bed elevation would be useful for river management. However, it is difficult to predict sediment transport at the bed including the complex surface and the substrate structure in the river. There are still some problems to be solved in estimating flow resistance considering both bed surface and vertical condition, and it lead to difficulty to estimate sediment transport. Therefore, a series of flume experiments were conducted in order to examine flow resistance and velocity distribution near bed surface. These experiments indicated the importance of both surface and substrate structure of river bed for prediction of sediment transport.
\end{abstract}

Key Words : Surface roughness, velocity distribution, PIV, river materials

\section{1.はじめに}

解析技術の向上を受け，高解像度で流れと土砂移動の 解析が行われるようになってきた。こうした解析を通じ て，例えば，石㗂河川など相対水深が小さな場で石の形 状などを取り込むことの重要性などが改めて指摘されて いる1)。一方で，高解像度になればなるほど，実河川の 砂㗂の形状，大きさ，それぞれの存在割合をどのように 捉えた上でどの程度解析等に組み込む必要があるかを見 極めていく必要がでてくる，また，礫の形状や大きさの ばらつきの重要性は, 相対水深が小さい場に限ったこと でなく, 相対水深が大きな場でも流砂特性等に少なから ず何らかの影響を与える可能性を持っている。 そのため, 近年広く用いられている平面二次元解析においても現地 への適用を踏まえると粗度の決め方，掃流力や流砂量の 算定方法などいまだ多くの課題が残っている.

古くから行われている流速分布を取り扱った研究は, 自然の河床材料を意識しながらも球形粗度を取り扱うこ とが多かった ${ }^{2)-5)}$. 流速分布が対数則に従うとする場合 に原点の位置，等価粗度の評価が問題となるが，球を密 に並べた場合などは，0点は粗度頂部より $0.25 d$ 程度下方 にとり，等価粗度は直径 $D$ で取り扱うのが良いと考えら れてきたの.しかし，自然の河床材料では粒子ごとに粒 径や形状も異なり, 河床表層の碩頂部位置もばらつきが
でるため河床基準面の決定すら難しい問題となる. その ため，等価粗度の評価は粒径を基準として0.5〜4倍程度 とするなど幅をもって評価されている.

こうしたことを踏まえると, 河床材料の特徵によって 粗度の取り扱い方法や流速分布は変化すると考えられ, 当然ながらこれらは流砂量の算定にも密接にかかわって くる.ここで，例えば，数值解析等で広く使用されてい る芦田道上式》について考える。この式は，掃流粒子の 単位面積当たりの個数と運動中の砂粒子の平均速度の積 で掃流砂量を表現しており，式（1）のように示される.

$$
\begin{aligned}
q_{b^{*}} & \equiv \frac{q_{b}}{\sqrt{(\sigma / \rho-1) g d^{3}}} \\
& =\frac{\beta_{u} \phi_{d}}{\mu_{R}} \tau_{*}^{\frac{3}{2}}\left(1-\frac{K_{G} \tau_{*_{c}}}{\tau_{*}}\right)\left(1-\sqrt{\frac{\beta_{c} \tau_{*_{c}}}{\tau_{*}}}\right)
\end{aligned}
$$

ここに, $q_{\mathrm{b}^{*}}$ : 無次元流砂量, $q_{\mathrm{b}}$ : 流砂量, $d:$ 河床材料 粒径, $g$ : 重力加速度, $\sigma$ : 砂の密度, $\rho:$ 水の密度, $\tau_{*_{\mathrm{c}}}$ : 無次元限界掃流力, $\phi_{\mathrm{d}}$ : 流送粒子中心部での流速と 摩擦速度の比, $\mu_{R}$ : 動摩擦係数, $\beta_{\mathrm{c}}$ : 粒子速度が流送流 速と同じになる掃流力と限界掃流力との比, $K_{\mathrm{G}}$ : 河床底 面で流れが受け持っているせんだん力と限界掃流力との 比とする.

芦田らがこの式を導出寸るにあたり，砂碟の移動速度 
を見積もる際の等価砂粗度や砂碩の存在高さ，また，河 床付近での全せん断応力のうち限界掃流力をわずかに上 回る程度が流体に受け持たれているなどの仮定が入って おり, 様々な研究者による研究成果および実験值と照ら し合わせながら，最終的にパラメータを決定している. ただし，こうしたパラメータは砂磎の特徴などによりあ る程度修正が必要と考えられ，ほぼ同じ粒径であっても 形状等の違いにより砂碮の表層構造や流送砂䃇の平均的 な高さや等価砂粗度の評価方法は一様な值ではなく, 若 干の違いが現れると考えられる.さらに, 河床構成材料 により流速分布が異なれば限界掃流力の評価にも影響が 現れる可能性がある．ちなみに，著者が以前行った研究 において流砂量式の適用性を検討したところ, 通常17と されている $\beta_{\mathrm{u}} \phi_{\mathrm{d}} / \mu_{R}$ の值は材料によって変化することが確 認されている8. また, 辻本ら ${ }^{9}$ は様々な流砂量式をべー スに勾配が急な場で適用を検討し，芦田道上式がベース の式として優位であると結論付けている. ただし，ここ では材料特性の違いについてはまったく言及していない が，勾配による重力の効果や相対水深の小さな場での流 速分布が異なる効果を考慮し, 限界掃流力の評価や芦田 道上式の係数を修正する必要があることを示している.

上記のような流砂量算定時の問題を意識しながら，ま ず，粒径のみでとらえがちな河床材料と粗度の関係につ いて単純な実験を行い検討する，特に，粒径のみで評価 されがちな等価粗度について天然の大㗂を用いて表層の 凹凸を変えた場合や底層の磁間に砂で充填された場合を 対象に粗度係数の評価について考察する. あわせて，比 較的容易に実施できるようになったPIV解析を水路実験 に援用し，河床付近の流れを詳しく調へ，河床底層が及 ぼす流速分布への影響を検討することにした．今回の検 討は, 将来的に流砂の問題に発展させることを視野にい れており，例えば，実河川や混合粒径で構成された河床 で粗度のとらえ方などにつなげていきたいと考えている。 なお，本研究で用いる天然の大碩は，ホームセンターで 購入できる天然白玉砂利を用いており, 球形と異なりあ る程度大きさがそろっているが，それぞれ異なる形状を 持つ材料として使用している.

\section{2. 実験で用いる河床材料の特徵}

\section{(1) 大礫の形状特性}

まず, 本研究で用いる主材料について, 形状の特徵を 調べた結果を示す．実験で用いる大磎群から50個をピッ クアップして, 平坦な面に置いた状態で上から見た際の 長径, 短径に加え, 高さを計測した. その結果, 長径の 平均值は, $36.15 \mathrm{~mm}$, 長径, 短径, 高さの平均值は, $27.65 \mathrm{~mm}$ となった. 本材料の代表粒径は長径の平均值を 用いて，36.1mmとした。 また, 各個の短径, 高さを長 径で除した值をグラフにまとめると図-1のようになり, 短径も礫高さもほぼ長径の5割以上ある比較的丸みのあ る材料とであることがわかる.

\section{（2）表層凹凸と間隙特性}

流水により堆積した河床材料は覆瓦状構造等特有の配 列を作ることが予測されるが，本研究で用いた河床材料 が丸みを帯びていることもあり，ここでは，人為的で あっても密に敷き均せば内部骨格構造はある程度のばら つきをもちつつも均一になると考え, 鉛直方向の間隙特 性等を調べることにした，まず，幅 $32.5 \mathrm{~cm}$ ，長さ $42.5 \mathrm{~cm}$ のコンテナに礫をできるだけ均一に敷均し， $20 \mathrm{~cm}$ 四方 枠の領域でポイントゲージを用いて表層に出ている碩頂 部を計測し，そのばらつきを把握した。 その後，コンテ ナに少量の水を加え, マノメータを用いて内部の水位を 計測することで，流入水量に対する水位上昇を計算し， 鉛直方向の間隙率の変化を調べた. 引き続き, 図-2に示 したパターンで表面の第一層に碩を加えることで表層状 態を変え，同様な計測を実施した。 なお，この実験は複 数回行い, その結果の一部を図 -3 , 図-4に示す. これら の図より，密に敷いた河床の䃯数を $\mathrm{N} と し て ， 1 / 4 \mathrm{~N}$, 1/2N加えていくと, 䃯頂部高さのばらつきは, 密に敷い た河床の二倍になっていることが分かり，それに応じて， 間隙比の鉛直分布も変化することがわかる.

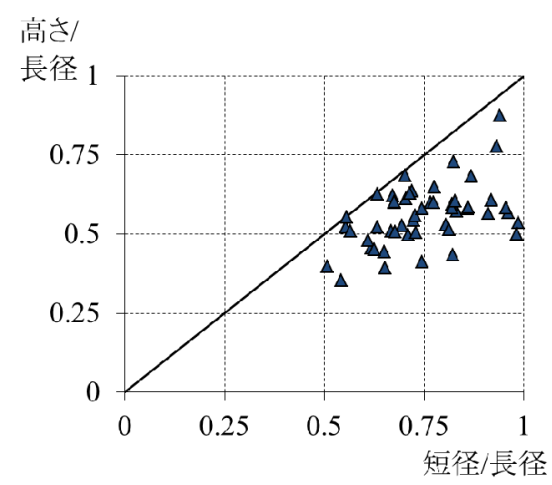

図-1 河床材料の形状特性

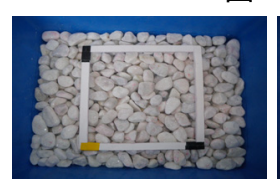

Pattern(1)

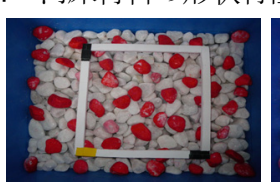

Pattern(2)

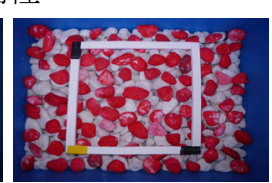

Pattern(3)

\begin{tabular}{|c|c|}
\hline Pattem(1) & $\begin{array}{l}\text { 碟を } 3 \text { 層密に上層まで敷き詰める } \\
\text { (このときの表層揅数を } \mathrm{N} \text { とする) }\end{array}$ \\
\hline Pattem(2) & Pattern(1)の表層に $1 / 4 \mathrm{~N}$ の碟を乗せる \\
\hline Pattem(3) & Pattern(1)の表層に $1 / 2 \mathrm{~N}$ の碟を乗せる \\
\hline
\end{tabular}

図-2 河床構造パターン

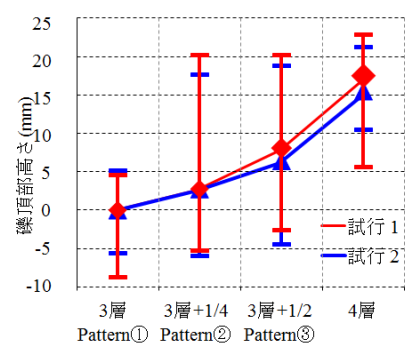

図-3 喼頂高さの平均, 最大, 最小の関係 


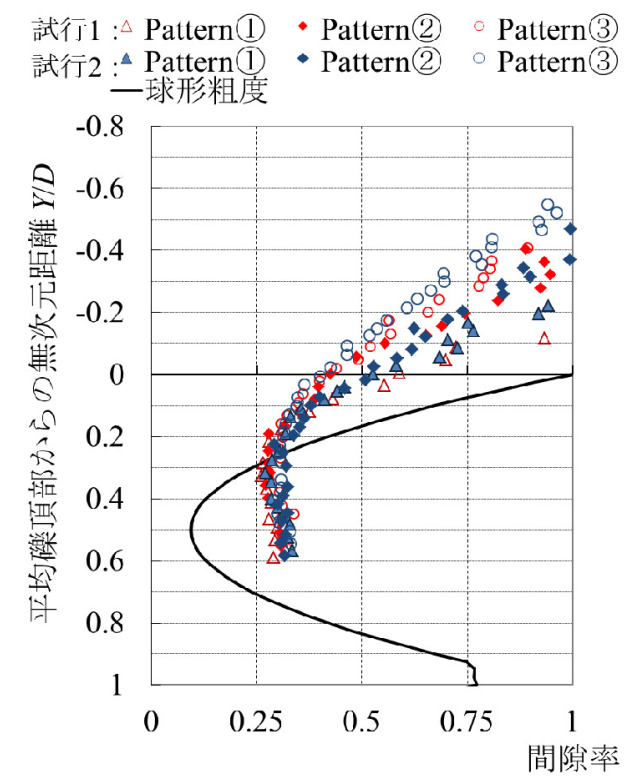

図-4 間隙率の鉛直分布

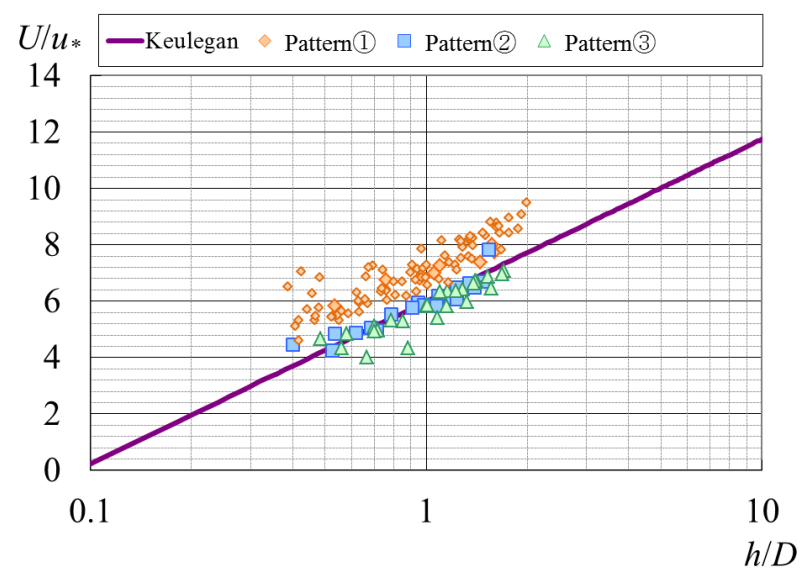

図-5 流速係数と相対水深の関係

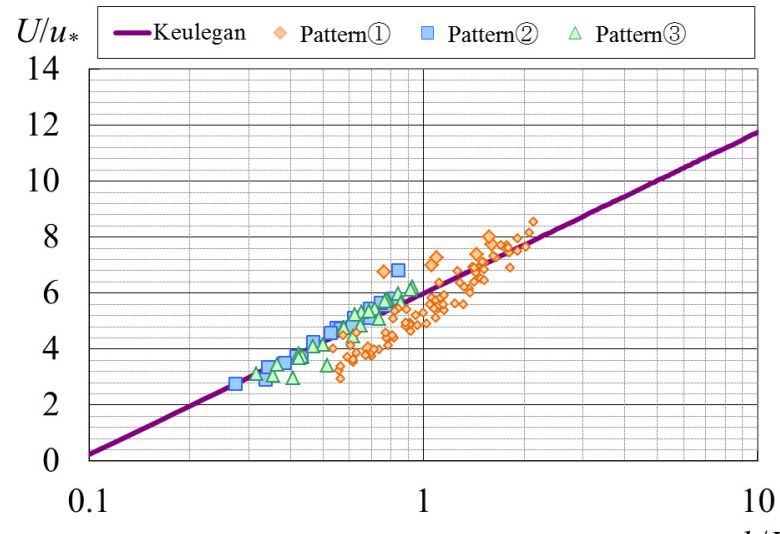

図-6＼cjkstart流速係数と相対水深の関係 （水深および等価砂粗度を補正）

\section{3. 河床構造と粗度特性}

\section{（1）河床表層パターンによる粗度特性の変化}

ここでは2章で示した特徵を持つ大碟を幅 $30 \mathrm{~cm}$ の水路 に長さ $7 \mathrm{~m} に わ た り$ 敷均した河床上に通水し，流量と水
位の関係を調べた結果を示す，実験では，勾配を $1 / 60$, $1 / 80,1 / 100$ に変化させ，流量とともに，水路中央部の $4 \mathrm{~m}$ 区間を $25 \mathrm{~cm}$ おき，水位，河床高を計測し平衡状態 を確認しながら実験した．また，水位および河床高は， 礫頂部の平均值を基準としてポイントゲージで計測し， それぞれ平均值を算出した.

この結果を整理し，2章（2）に示した材料の配置パ ターンごとに，断面平均流速 $U$ と摩擦速度 $u_{*}$ の比である 流速係数U/u* と相対水深の関係を調べると，図-5の結果 が得られた。 なお，摩擦速度 $u *$ *，重力加速度 $g$, 水深 $h$, 河床勾配 $l_{\mathrm{b}}$ を用いて $\left(g h I_{\mathrm{b}}\right)^{0.5}$ とし, この図の平均流速は平 均碩頂部からの水面位置を水深として用いて算出してい る. また，ここでは，粗面乱流の対数分布則から導かれ る式（2）においてカルマン定数 $k=0.4, B r=8.5$ とした Keulegan式を併せて示している.

$$
\sqrt{\frac{8}{f}} \equiv \frac{U}{u_{*}}=\frac{1}{\kappa} \ln \left(\frac{h}{k_{s}}\right)+B r-\frac{1}{\kappa}
$$

ここに, $f$ : 摩擦抵抗係数, $k_{\mathrm{s}}$ : 等価粗度, $B r: y=k \mathrm{~s}$ とな るU/u*の值である.

これまでの流速分布からの河床位置の補正の議論を考 えると, 平均砅頂部は河床の 0 点として妥当でない可能 性があるし，等価粗度も変化させる必要が考えられる。 そこで，等価砂粗度については，表層パターンによって 礫頂部高さの最大值, 最小值の差が異なり表層パターン (1)に対し，(2)，(3)では2倍となっていたことを踏まえ， 表層パターン(1)では河床材料粒径 $D$ を, 表層パターン(2), (3)では河床材料粒径Dの二倍を用いることとした。 また， 河床高の補正については，以下の考えのもとに実施する. まず，既往の研究より球形粗度のとき $0.25 D$ 程度下がっ た位置で0点を取るが，図-4より0.25D下がった高さの間 隙率が平均間隙率となる 0.35 程度の值を示寸ことがわか る.このことと, 実験で用いた材料の間隙率が平均碩頂 部（河床の0点）から $0.15 D$ 下方で $0.3 \sim 0.35$ 程度に収束し ていることを踏まえ，河床高を $0.15 D$ 下方一修正し水深 の補正を行うことにした，その結果，図-6のようになり， 表層Pattern(2)，(3については，Keuleganの式により近づ くことが分かった．ちなみに，表層Pattern(1)については, Keulegan式よりU/u*の值が下回りばらつきが大きな結果

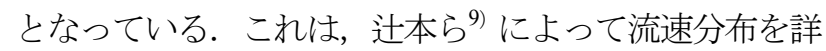
しく調べたうえで同様な検討を行った結果と類似してい る。つまり, 相対水深が小さい今回のケースは, 式 （4）中の $B_{\mathrm{r}}$ がNikuradseの実験より減少するために Keulegan式より $U / u * の$ 值が下回る結果となった可能性が ある.この理由については，4章で検討する.

\section{（2）河床底層に砂が存在した場合の粗度特性の変化}

次に，幅 $20 \mathrm{~cm} の$ 可変急こう配水路を用いて下層の砅 間を砂で埋め, 河床鉛直構造を変化させた実験について 述べる。ここでは，勾配は，1/50，1/100，1/200に設定 した。 また，以前実験で検討した経験を踏まえ，大砂間 
に砂を流した場合に礫の露出率が変化し現象が複雑にな ることを避け，今回は，河床下層の礫間に三河珪砂 4 号 (平均粒径 $0.88 \mathrm{~mm}$ 程度) を入れて流砂が存在しない条 件で実験を行うことにした。下層の礫間への砂の挿入は, 表層大㗂を除いて礫間隙に砂を入れた後，大砂を戻すこ とで実施した．また，実験前に勾配を急にした状態で大 流量を通水し表層近くの砂を排除した。結果として平均 礫頂部高さに対し18mmほど平均的に砂面を低く設定す ることとなり，全実験を通じて砂の流送はない状態にし ている. なお，砂面位置は大礫径を $D=3.61 \mathrm{~cm}$ とすると， $0.5 D$ 程度下に設定したことになる.

ここでは，前節と同様に $k \mathrm{~s}$ 粒径 $D$, 河床高を $0.15 D$ 低 くして整理した結果を図-7に示す。これによると，どの ケースも相対水深 $h / D か ゙ 1$ 周辺になるとKeulegan式より下 方へずれることがわかる。.また，ごくわずかではあるが， ほとんどのケースでU/u*の值が砂を挿入した河床の值ほ うが上にある。ただし，それほど大きな差にはならず， 粗度抵抗としては下層の状況をほとんど考慮しないでも 良いと言える。

\section{4. 表層状態が同様で鉛直構造が異なる河床の流 れ構造の違い}

\section{（1）PIVを用いた流速分布の計測}

本章では，3章の結果について詳しく調べるため, 特 に（2）節の条件で，底面付近に着目した流速分布の計 測を行う。相対水深が小さい場で流速分布を計測するに あたり，水中に計測機器を入れず，かつ，面的に計測で きるPIV解析を採用する．実験では，図-8のように水路 内に鏡を入れることで，レーザーを壁面から $5 \mathrm{~cm}$ の位置 に流下方向一平行になるように入れ，水路壁外側から高 速度カメラを用いて流下寸るダイヤイオンをトレーサー 粒子として撮影し, PIV解析を行う。解析用画像として, カトウ光研製高速度カメラK5 5 用い, シャッタース ピード1/2000，撮影速度2000fpsで13秒程度のものを用意 した. 撮影範囲は, 画素数 $640 \times 480$ の画面に水深スケー 儿程度と河床付近 $1 \mathrm{~cm}$ 程度の範囲をそれぞれおさめた。 取得画像はカトウ光研製Flow-Expertを用いて処理してい る. また, レーザー光源としてカトウ光研製PIV Laser G シリーズ・200Mwレーザーを使用している.

本実験での計測ケースは，表-1に示寸とおりである.

PIV解析は高解像度で瞬間值が求まり，その值を用い て各計測点の時間平均值やレイノルズ応力を求めている。 さらにこれを計測断面で平均し, 代表值を求めることに した. なお，空間的に流速分布は多少変化しているが, 時間平均した值に対し, 計測断面における各計測点での 流速のばらつきは図-9に示寸程度で微小である。特に, 解析をまとめた例の図-9における面的な解析事例を図-10 に示寸と，瞬間的には，同一断面でもばらつきが大きい し, 底面付近は特に硯の存在により変化する. しかし,
詳細な砂間以外は断面位置を多少変化させても計測の時 間および断面平均值にそれほど変化がないため, ここで は一断面で平均した值を代表として議論することとした.

PIV解析用の画像は, ケースごとに水深が異なるため 高さ方向にぎりぎり河床から水面がおさまるように設定 し，取得している，そのため，各ケースで異なるスケー ルのメッシュを用いて直接相互相関法により解析を行っ ている.また，底面付近の流れの詳細を別途計測してお り, こちらは画像高さが $5 \mathrm{~mm}$ 程度になるような撮影を 行っている. また, 解析時の相関係数はほとんどのケー スでおおよそ 0.8 程度を保っているが，ごくたまに相関 が低いものもあるため 0.5 以下を示寸数值は除去し, 周 辺解析值から補間を行うこととした．なお，水表面付近 については，波打ってしまう関係からノイズが入りやす く, 解析精度が確保されないためあらかじめ解析領域か

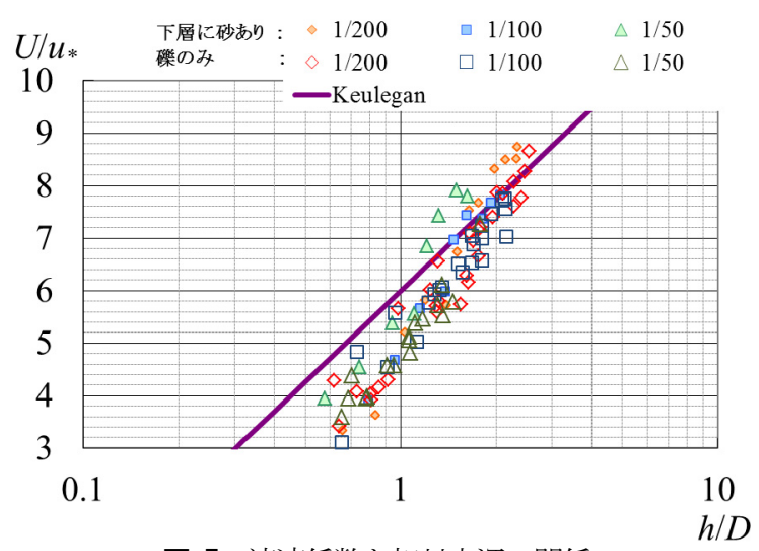

図-7 流速係数と相対水深の関係 （磕のみの場合と礫間に砂がある場合）

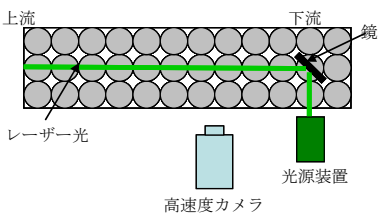

図-8ＰIVのための撮影

\begin{tabular}{|c|c|c|c|c|c|c|c|}
\hline 勾配 & $\mid \begin{array}{ll}\boldsymbol{h} & (\mathrm{m})\end{array}$ & $h / D$ & $\boldsymbol{u}_{*}$ & $\begin{array}{l}\text { 流量 } \\
\left(\mathrm{m}^{3} / \mathrm{s}\right)\end{array}$ & \begin{tabular}{|c|}
$\begin{array}{c}\text { 断面平均流速 } \\
\mathrm{U}(\mathrm{m} / \mathbf{s})\end{array}$ \\
\end{tabular} & $U / \boldsymbol{u}$ * & \\
\hline $1 / 50$ & 0.0222 & 0.6161 & 0.0660 & 0.0013 & 0.2992 & 1.433 & 砂あり \\
\hline $1 / 50$ & 0.0360 & 0.9962 & 0.0840 & 0.0042 & 0.5827 & 2.195 & 砂あり \\
\hline $1 / 50$ & 0.0486 & 1.3458 & 0.0976 & 0.0075 & 0.7680 & 2.489 & 砂あり \\
\hline $1 / 50$ & 0.0215 & 0.5962 & 0.0649 & 0.0012 & 0.2902 & 1.413 & 礫のみ \\
\hline $1 / 50$ & 0.0389 & 1.0765 & 0.0873 & 0.0044 & 0.5704 & 2.067 & 硫のみ \\
\hline $1 / 50$ & 0.0514 & 1.4231 & 0.1003 & 0.0079 & 0.7713 & 2.431 & 礫のみ \\
\hline $1 / 100$ & 0.0207 & 0.5735 & 0.0450 & 0.0009 & 0.2164 & 4.805 & 砂あり \\
\hline $1 / 100$ & 0.0382 & 1.0586 & 0.0612 & 0.0032 & 0.4144 & 6.771 & 砂あり \\
\hline $1 / 100$ & 0.0508 & 1.4076 & 0.0706 & 0.0059 & 0.5757 & 8.158 & 砂あり \\
\hline $1 / 100$ & 0.0587 & 1.6262 & 0.0758 & 0.0075 & 0.6407 & 8.447 & 砂あり \\
\hline $1 / 100$ & 0.0222 & 0.6142 & 0.0466 & 0.0010 & 0.2304 & 4.944 & 礫のみ \\
\hline $1 / 100$ & 0.0396 & 1.0975 & 0.0623 & 0.0031 & 0.3937 & 6.318 & 礫のみ \\
\hline $1 / 100$ & 0.0504 & 1.3949 & 0.0702 & 0.0052 & 0.5145 & 7.324 & 硫牰 \\
\hline $1 / 100$ & 0.0616 & 1.7059 & 0.0777 & 0.0077 & 0.6228 & 8.017 & 礫のみ \\
\hline $1 / 200$ & 0.0212 & 0.5868 & 0.0322 & 0.0006 & 0.1515 & 4.702 & 砂あり \\
\hline $1 / 200$ & 0.0379 & 1.0503 & 0.0431 & 0.0022 & 0.2887 & 6.699 & 砂あり \\
\hline $1 / 200$ & 0.0516 & 1.4300 & 0.0503 & 0.0042 & 0.4046 & 8.045 & 砂あり \\
\hline $1 / 200$ & 0.0687 & 1.9017 & 0.0580 & 0.0072 & 0.5254 & 9.058 & 砂あり \\
\hline $1 / 200$ & 0.0220 & 0.6101 & 0.0329 & 0.0008 & $\begin{array}{ll}0.1809 \\
\end{array}$ & 5.505 & 礫のみ \\
\hline $1 / 200$ & 0.0341 & 0.9450 & 0.0409 & 0.0018 & 0.2688 & 6.574 & 磞のみ \\
\hline $1 / 200$ & 0.0514 & 1.4234 & 0.0502 & 0.0040 & 0.3893 & 7.758 & 磎のみ \\
\hline
\end{tabular}


ら外すことにした.

解析結果をまとめた例を図-9に示寸とともに，面的な 解析事例を図-10に示寸，なお，図-9には，解析結果をプ ロペラ流速計の測定值や断面平均值と比較した例を示し ているが，プロペラ流速計での計測值を参考にPIV解析 の精度を検証したうえで，この後の検討を行っている.

（2）底面付近の流速分布の特徵

PIV解析より得られた各勾配における底面付近の流速 分布とレイノルズ応力を図-11に示す。これによると， どのケースも相対水深1以下のところで，対数則の傾き に沿った流れが現れており，対数則が下方まで成立して いることがわかる，また， wake-regionにしては減衰が大 きいようにも思われ要因等の判断が難しいが，水表面付 近で減速領域が確認される結果となった.

ここで，河床表層付近の流れについて確認すると， $y / D$ 值が 0.1 になると, 礫間が砂で埋まっている場合に $u(y) / u_{*}$ の值が各ケースともに一定值周辺に落ち着き, 礫 のみの河床の場合はそれぞれ異なる值に収束することが わかる. 特に, $u(y) / u_{*}$ の一定となる值は, $u_{*}$ の值が同じ でも下層に砂がある場合のほうが大きく,$y / D$ の值も大 きくなる，これは，礫のみの場合間隙が大きく，底面付 近の流速に対し浸透流が無視できない大きさとなるため と考えられる. 特に, 浸透流が表流水の流れに及ぼす影 響は, これまで, 中川ら ${ }^{10)}$ や山田ら ${ }^{11)}{ }^{12)}$ などにより検 討されているように, 浸透流との水塊のやり取りがある ため，減速する領域が広がると考えられる．また，この ことを裏付けるように下層の間隙を砂で充填した河床よ り碩のみの河床で明らかにレイノルズ応力が底層付近で 大きいことも確認できるし，礫のみの河床条件では解析 画像において粗度付近で生じる渦が上方へ運ばれていく ことが確認できる.こうした状況により河床下層の間隙 の充填が流れ構造に影響を及ぼすと言える.

なお，本結果より，礫間の砂の有無にかかわらず，勾 配にもかかわらず, $y / D=1$ のとき $u / u_{*}$ の值，つまり， 式（4）の $B_{\mathrm{r}}$ の值がどのケースもほとんど変わらないこ とも確認できる. 図-11とあわせて，勾配1/200の流速分 布を図-12に示すが，底面付近の流速分布形状が異なる のが見てとれる.

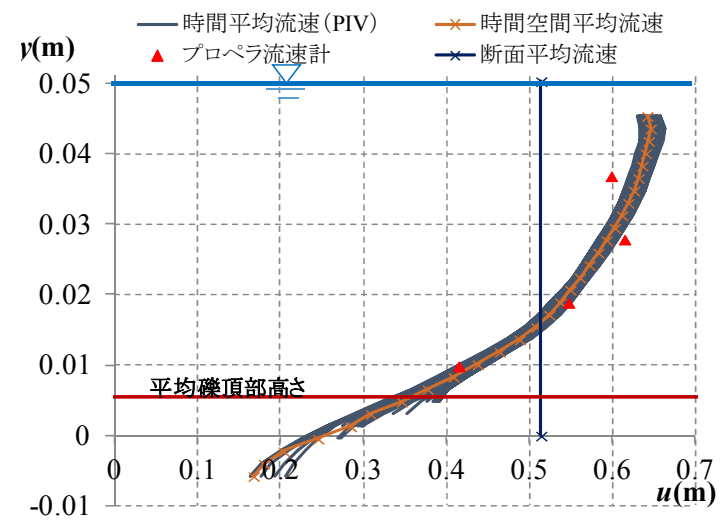

図-9 PIVおよびプロペラ流速計による流速分布 $(1 / 100 ，$ 水深 $0.050 \mathrm{~m}$ のケース)
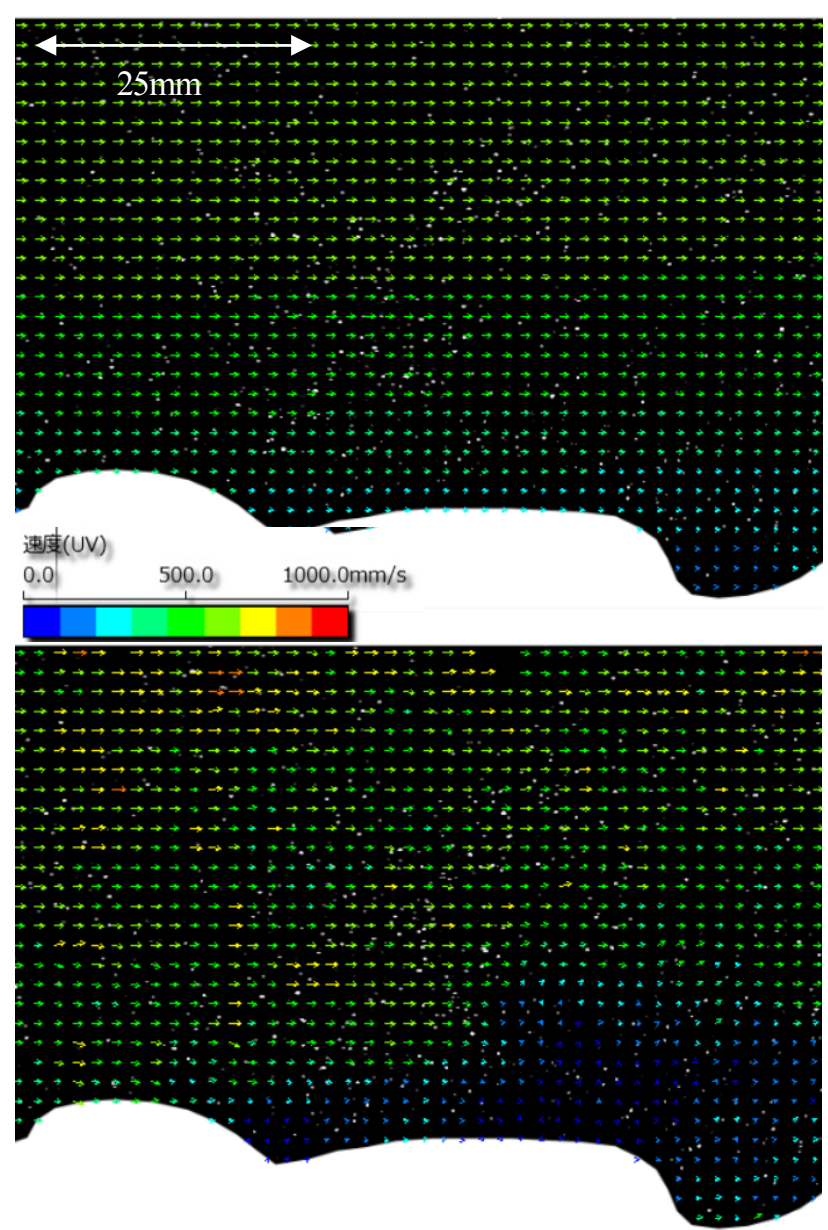

図-10 流速分布の例（上図 : 平均值，下図 : 瞬間值)

\section{5. おわりに}

本研究では，天然碩を対象に河床表層状態と下層の間 隙状態を変化させた河床で水深と流速を調べた実験の結 果を整理し, 粗度の取り扱いについて検討した。 また, あわせてPIV解析を用いて底面付近の流速分布を調べた。 これらの結果を検討し, 以下のことが分かった.

・河床材料の粒径情報だけでなく表層構造の違いによる 凹凸情報により，粗度の大きさを変化させる必要がある。 - 河床下層における砂の充填の有無は, 粗度係数の評価 にそれほど影響しない，ただし，底面付近の詳細な流速 分布については違いが現れる.

・河床構造に間隙が存在し浸透流が存在する場合, 従来 の研究成果と同様に河床間隙の流れが表流水流れに影響 を与えることが確認できた。つまり，底層の流速の評価 には, 河床の凹凸だけでなく, 河床間隙状態の把握が必 要となる.

今回の結果を踏まえると，混合粒径構成河床の課題が 見えてくる. 表層が碩でおおわれているとき，下層の材 料にかかわ加らず, 粗度としては表層の碩構造で考えても よい. ただし, 河床付近の流速は, 下層の状態で大きく 変化するため, 細砂の流入等があった際にはその影響は 

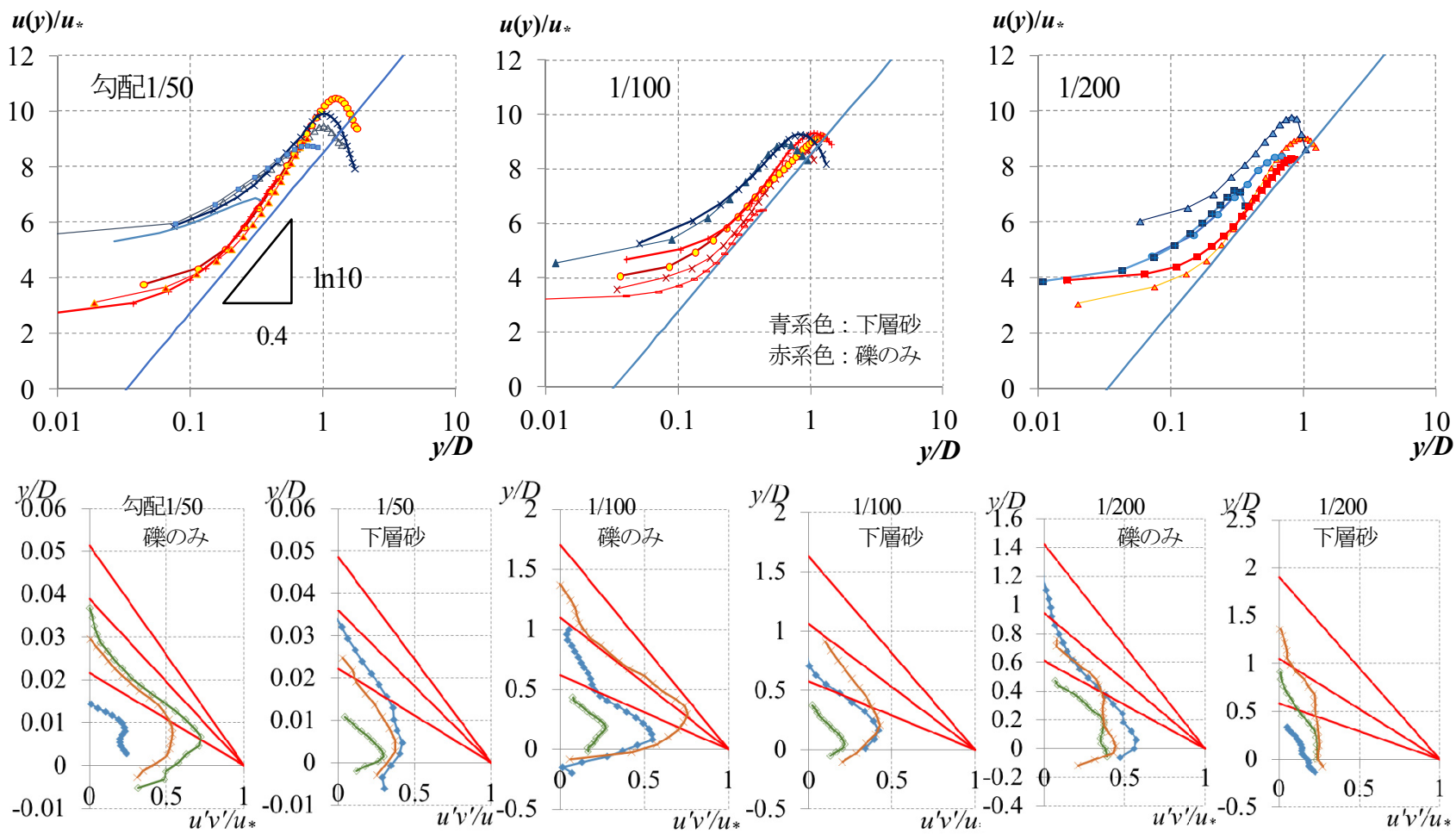

図-11 勾配別流速分布およびレイノルズ忘力分布

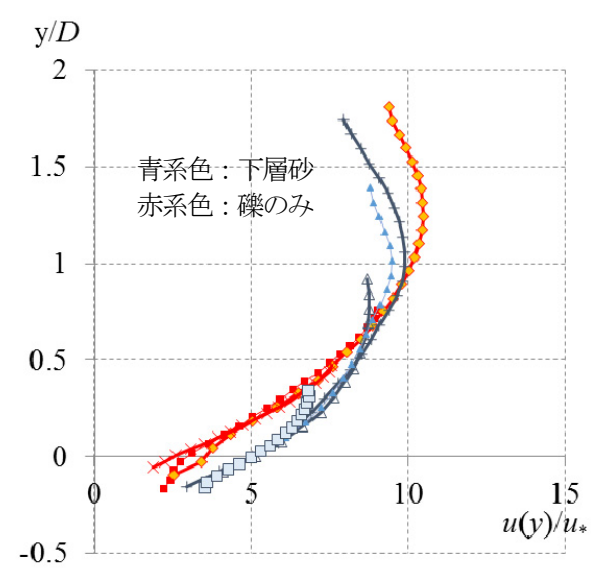

図-12ＰIVによる流速分布（1/200のケース）

異なってくる.

なお，今回の検討ではPIVによる底面流れの計測結果 を示し，有用なツールとしての可能性が見えてきた．今 後, 流砂量算定, 特に, 混合粒径における掃流力等の正 しい見積りのためにも，PIV解析を利用して河床内部構 造〜表層凹凸〜粗度の関係を検討していくことを考えて いる.

謝辞 : 本研究を実施するにあたり, PIV計測等でカトウ 光研（株）の藤村氏に多大なる助言をいただいた. また, 様々な実験は，2014年度の4年生をはじめこれまで名城 大学河川工学研究室に所属した学生の補助があり実現し ている.ここに記し，謝意を表する.

\section{参考文献}

1) 田所弹，福田朝生，福岡捷二 : 等価な粒度分布を有寸る球と 石砂で構成される二つの数值移動床上の粒子運動の比較検討, 土木学会論文集B1(水工学)，Vol.70， No.4，I 961-I 966，2014.

2) 芦田和男, 大同淳之, 高橋保, 水山高久 : 急勾配流れの抵抗 と限界掃流力に関寸る研究, 京都防災研究所年報第 16 号, pp.481-496, 1973.

3) 神田徹, 土井和吉 : 粗面開水路における浅い流れの抵抗則, 第25回水理講演会論文集, pp.105-112，1981.

4) 神田徹, 鈴木勝士 : 球形粗度の床面における浅い流れの抵抗 特性，土木学会論文集，第357号，II-3，pp.65-74， 1985.

5) 中川博次, 辻本哲郎, 清水義彦: 相対水深の小さな流れの構 造に関する実験的研究，土木学会論文集，第423号，II-14, pp.73-81, 1990.

6) 中川博次 - 辻本哲郎 : 移動床流れの水理，第三章，技法堂出 版, 1986.

7) 芦田和男，道上直規 : 移動床流れの抵抗と掃流砂量に関する 基礎的研究，土木学会論文集，第206号，pp.59-69.1972.

8) 溝口敦子 : 大喼間を流孔る砂の流砂量算定に向けた相対水深 が小さい場での粗度抵抗・有効掃流力の評価に関する実験的 検討, 応用力学論文集, 第13巻, 土木学会, pp. 869-876, 2010 .

9) 辻本哲郎, 細川迭男 : 急勾配水路における砂の限界掃流力と 流砂量，土木学会論文集第 411 号，II-12，pp.127-134， 1989.

10) 中川博次, 袮津 家久: 透水性開水路乱流場における主流 と浸透流との相互作用, 土木学会論文報告集, pp.81-89, No.244, 1969.

11) 山田 正, 川端 規之 : 浸透層上の流れの抵抗則に関する理 論的研究，土木学会論文集，325号，pp. 69-80， 1982.

12) 山田 正, 川端 規之 : 浸透層上の流れの抵抗則に関する実 験的研究，土木学会論文集，325号，pp. 81-91，1982.

(2014. 12. 20受付) 